\title{
Interpreting the Beaker phenomenon in Mediterranean France: an Iron Age analogy
}

\section{Olivier Lemercier*}

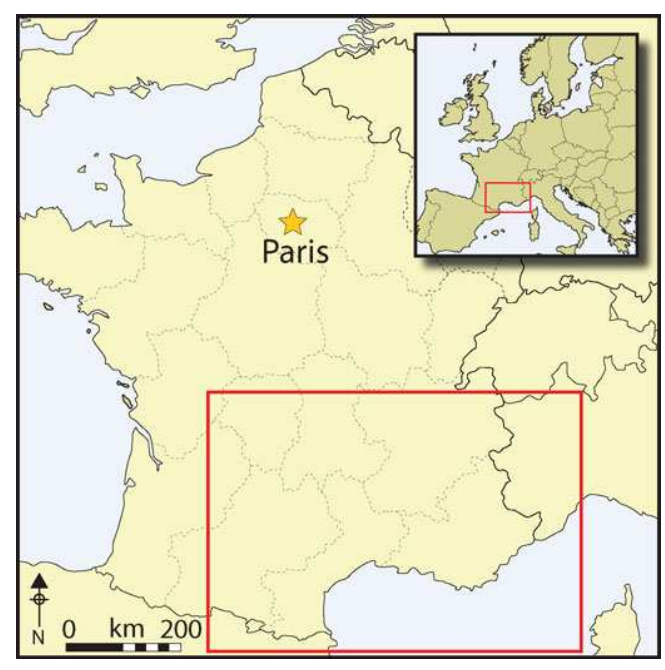

The author offers a new descriptive explanation of the Beaker phenomenon, by focusing on Mediterranean France and making reference to the Greek influx in the same area 2000 years later. In the Iron Age, the influence began with an exploratory phase, and then went on to create new settlements and colonise new areas away from the coast. The Beaker analogy is striking, with phases of exploration and implantation and acculturation, but adjusted to include a final phase where Beaker practice was more independent. Comparing the numerous models put forward to explain $i$, the author shows that immigration and a cultural package are both aspects of the Beaker phenomenon.

Keywords: Iberia, France, Mediterranean, Beaker, Campaniform, third millennium BC, Iron Age, protohistory, first millennium BC

\section{Context}

For more than a century the discovery in many regions of Europe of decorated Bell Beakers associated with weapons and objects of personal adornment, often found in individual burials, has fascinated researchers, who have tried to explain what is now conventionally called 'the Beaker phenomenon'. There have been many proposals for its area of origin (Iberian Peninsula, the Netherlands, Central Europe...), and explanations of its spread over a whole continent (migration of a warrior population, movement of individuals, of objects, of ideas, or fashion...). Yet there is still no consensus among researchers. As recently as 2001, Alain Gallay could state that "we must admit today that the very wide distribution over Europe of the Bell Beaker style of decoration still has no plausible explanation in economic

* Université de Bourgogne, UMR 6298 ArTeHiS, Bâtiment Sciences Gabriel, 6, Boulevard Gabriel, F-21000 Dijon, France (Email: olivier.lemercier@u-bourgogne.fr) (Translated by Madeleine Hummler) 


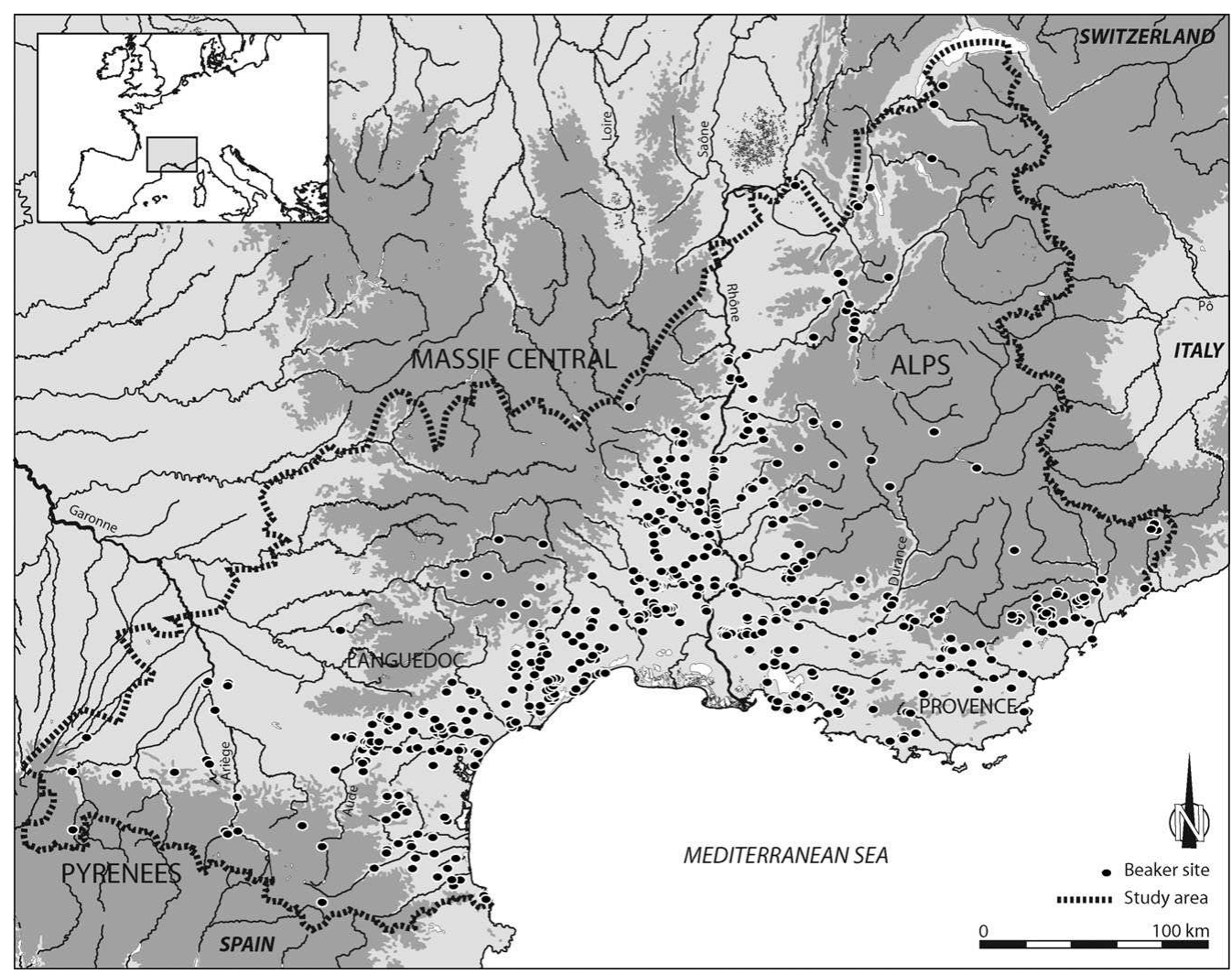

Figure 1. Distribution map of sites with Beaker assemblages in Mediterranean France.

terms, as there is no adequate ethnographic model" (Gallay 2001: 52). In this article we advance a model inspired not by ethnography, but by the later experience of the same region in the Iron Age.

The area of study, Mediterranean France, consists of an area between the Iberian and Italian peninsulas, stretching from the Pyrenees to the Alps; it is wide open towards the Mediterranean but also towards the interior of the continent, via the Rhône valley. Around 540 sites (Figure 1) with Bell Beaker material can be catalogued: some 170 burial sites, 230 settlement or domestic sites and 130 sites of indeterminate function. The proportion of habitation sites compared to burials is of great importance because it allows a good understanding of the assemblages and of the context in which Beakers appear. Four Beaker ceramic styles have been defined since the 1960s for certain areas of the Pyrenees and Provence and later extended to the whole of the region (Courtin 1967, 1974; Guilaine 1967, 1976). A reassessment of Beakers in south-eastern France, the eastern part of Mediterranean France, has allowed us to define more precisely the different styles and propose a threephase chronological sequence (Early, Recent and Late Beakers) based on data from over 310 sites which produced over 1500 decorated vessels (Lemercier 2004b, 2004c \& in press). In parallel, the past few decades have seen particularly active research on the Late Neolithic C) Antiquity Publications Ltd. 
as well as the Beaker episode in the region, thus providing a firm chronological framework (Figure 2) (Lemercier 2007; Lemercier et al. 2010).

\section{The archaeological data}

\section{The Early Beaker horizon}

Beakers first become visible in Mediterranean France between 2500 and $2400 \mathrm{cal}$ BC. This Beaker presence is characterised by pottery of Maritime or International style and the most common variants of its vessels (Figure 3.1). The extreme rarity of All Over Ornamented and All Over Corded (AOO and AOC) large beakers is notable and there are no coarse wares specific to the Beaker assemblages (Lemercier 2004a \& b). Nearly all the pottery is produced locally or regionally, but the techniques or practices used can differ from those of indigenous traditions (Convertini 1996, 2009). The tool assemblage comprises polished stone artefacts and bone, horn or antler objects that are difficult to distinguish from earlier artefacts of the Late Neolithic, as well as flint artefacts which are essentially locally produced; their debitage consists of small non-standard flakes made by direct percussion or on an anvil. The toolkit is limited in form. The percentage of arrowheads can be high (leaf-shaped, heart-shaped and lanceolate forms and tanged and barbed arrowheads with a variant with squared-off barbs). The remainder is characterised by end-scrapers, side-scrapers and splintered pieces (pièces esquillées) (Furestier 2007). Metal objects are few (awls with square section, daggers, Palmela points and ornaments). Settlements are generally small, containing one to four dwellings, oval in plan, with flagstone floors or with a surrounding low wall, some 50 to $60 \mathrm{~m}^{2}$ in surface area (Lemercier 2004b; Lemercier \& Gilabert 2009). The burial tradition is mainly collective burial in megalithic structures or in local caves or cavities, but a few individual burials are also known (Lemercier \& Tchérémissinoff 2011).

Beaker assemblages are encountered in two distinct types of context. On the one hand there are isolated vessels or small groups of very few vessels found within funerary or domestic contexts which belong to the local Late Neolithic tradition. A good example is provided by the single burial of Forcalquier - La Fare in the Alpes-de-Haute-Provence, which yielded a Beaker of mixed style (cord- and shell-impressed) found together with two beakers of the local Rhône-Ouvèze group (Lemercier et al. 2011). On the other hand there are contexts with much more substantial assemblages, consisting of several dozen decorated vessels found on settlement sites; there too they are systematically associated with elements that characterise the local Late Neolithic. The sites are small, naturally defended hill-top sites, more or less difficult to reach. All these sites are located along the Mediterranean coast and along the main rivers, such as at Châteauneuf-les-Martigues - Le Fortin du Saut (Furestier et al. 2007), Orgon - Les Calades (Lemercier 2004b; Furestier 2007) or SimianeCollongue - Le Col Sainte-Anne (Bocquenet et al. 1998) in the Bouches-du-Rhône. The interior has yielded only isolated Beakers.

Data relating to the economy reveal a Late Neolithic agro-pastoral type of society. On certain sites, the variety of hunted animals differs from indigenous practices but the contribution of hunting to local foodways remains very low (Blaise 2010). Contrary to a notion still occasionally peddled (Van der Linden 2006: 223), horses are no more

(C) Antiquity Publications Ltd. 


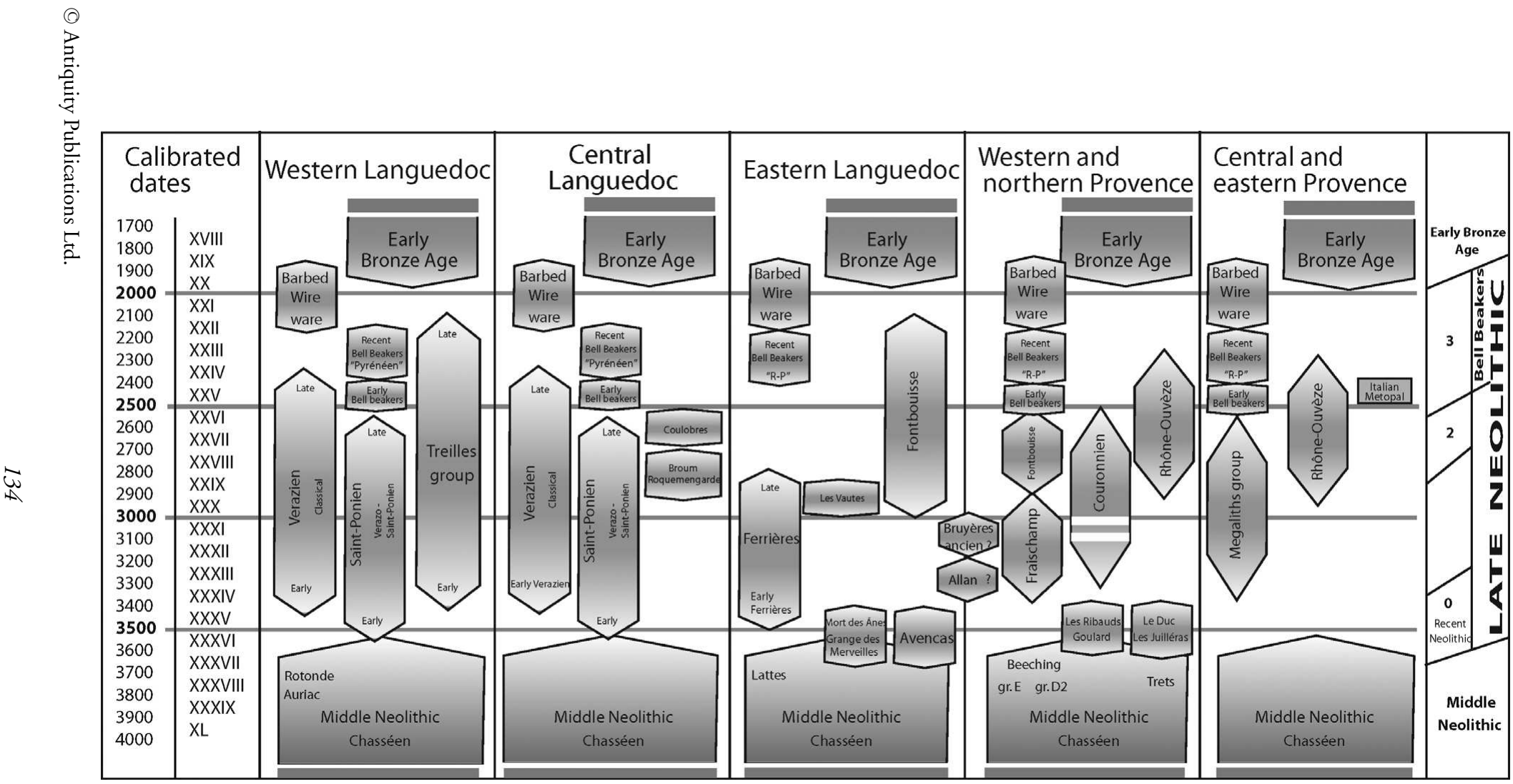

Figure 2. Chronological and cultural sequence of Mediterranean France at the end of the Neolithic. 


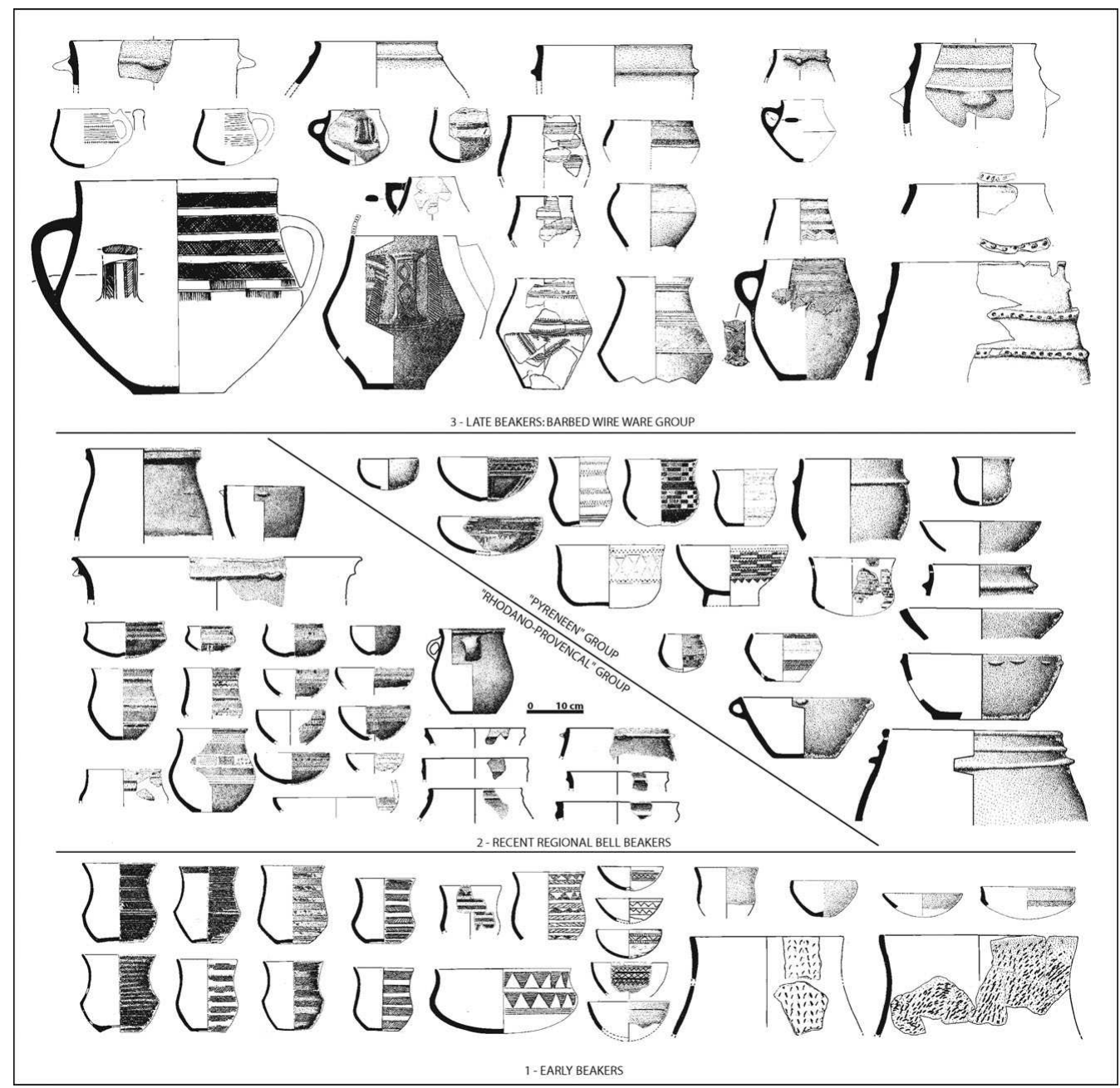

Figure 3. Beaker pottery in Mediterranean France by period (drawn after: Bill 1973; Sauzade et al. 1974; Courtin 1976, 1978; Sauzade 1983; Courtin et al. 1985; Guilaine et al. 1989, 2001; Barge-Mahieu 1992; Roudil 1993; Jallot et al. 1996; Vaquer 1998; Vital 2000; Buisson-Catil \& Vital 2002; Vignaud 2002; Ambert 2003; Leonini 2003; Lemercier 2004c).

common than in the previous Middle and Late Neolithic periods in the region (Blaise 2010: 267).

\section{The Middle Beaker phase}

The middle Beaker phase can be dated to between 2400/2350 cal BC and 2200/2150 cal $\mathrm{BC}$ in Mediterranean France. It is characterised by the presence of two distinct regional groups identified by different decorated pottery, but with a common coarse ware tradition. Geographically, the Pyrenean group occupies the west, from the Pyrenees to the middle of the Garonne valley and up to central Languedoc, whereas the Rhodano-Provençal group is

(C) Antiquity Publications Ltd. 
located in the east, from the eastern Languedoc to the Alps. The two groups exhibit a great variety of pottery forms (beakers, bottles, pseudo-bottles, large pots, handled jugs, bowls, dishes, cups) and beakers are no longer the dominant form. The two groups differ mainly in their decoration techniques (generally impressed in the Pyrenean group, incised and stamped in the Rhodano-Provençal group), arranged in horizontal zones, in bands which may or may not be separated by plain bands. A second significant departure from the previous phase is the existence of plain coarse wares, consisting of vessels used in preparation, cooking and storage, which are similar in both regional groups. Vessel shapes are often open or straight and the bases are mostly flat. The greater part of the assemblages comprises pots of medium size with a cordon applied below the rim or directly attached to the lip. These cordons are generally triangular in section and always smoothed. Pots with perforations arranged in a line below the rim and associated with a triangular cordon are quite frequent (Besse 2003; Lemercier 2004b) (Figure 3.2).

The lithic industry, better known in the Rhodano-Provençal group, shows strong links with the traditions of the local Late Neolithic. The raw material is mainly obtained locally in order to produce as many small flakes as possible. Splintered pieces (pièces esquillées) and scrapers (often thumb-nail scrapers) dominate the domestic assemblages and pieces produced by Late Neolithic specialists, such as large blades and daggers are reintegrated in the formal vocabulary, while new tools also make their appearance (microlith crescents and microdenticulates). Arrowheads are less frequent and tanged arrowheads with squaredoff barbs are no longer current (Furestier 2007). Metal objects of copper from a secure provenance are rare (awls and daggers). Among objects of personal adornment, V-perforated bone buttons and plain roughly arc-shaped pendants join the types of ornament known from the Late Neolithic. Wristguards, mostly made of stone (limestone, sandstone) are well documented.

The settlements show great variety and regional diversity: oval-shaped dwellings with flagstone floors in eastern Languedoc, post-built structures in the Rhône valley, and probably structures using mixed stone and timber in Provence (Lemercier 2004b; Lemercier \& Gilabert 2009). The burial rite consists of burials in caves and in monumental structures, except for a few rare individual burials of children (Lemercier \& Tchérémissinoff 2011). The sites are spread all over the region of study, including marginal and mountainous areas (Lemercier \& Furestier 2009).

\section{The Late Beaker phase}

This last phase is undoubtedly best anchored in time, with a number of dates ranging between 2150 and 1850/1800 cal BC. The decorated pottery belongs to the Beaker tradition in terms of arrangements of the decoration but also shows new traits in techniques of decoration and shape of vessels. The decoration is incised and/or of barbed-wire style (occasionally supplemented by stamped motifs), sometimes applied to the same vessel (Figure 3.3). The best represented vessel forms are beakers with usually a flat base, whose S-shaped profile is less curved or, on the contrary, more distinctly segmented than in the previous phase. Some barrel-shaped vessels, either biconical or with S-shaped profile, have a single handle and belong to large jugs. Smaller single-handled vessels with a simple or segmented profile

(C) Antiquity Publications Ltd. 
resemble cups. The coarse wares are clearly in the Beaker tradition. The flat-based vessels consist of simple and rounded, sometimes handled, containers. Cylindrical or barrel-shaped jars of various sizes can have one or two applied cordons located below the rim. Smoothed cordons are frequent but finger-impressed cordons are also known. The general layout of the motifs on the vessels is still in the Beaker tradition but some arrangements are recurrent: large square or rectangular panels limited by the handles of some vessels (Lemercier 2004b) (Figure 3.3).

The lithic industry also follows a strong Beaker tradition. Raw material procurement, debitage into flakes and the types of tools produced endure. The toolkit is still dominated by scrapers and leaf-shaped and tanged and barbed arrowheads as well as splintered pieces (pièces esquillées) (Furestier 2007). It is harder to define the rest of the material culture: only a few very rare small bronze awls, lozenge-shaped in section, seem to be typical. Settlements outnumber burial sites. There is a tendency towards occupying hill-top sites, as in the initial phase, but this time accompanied by fortification through enclosures, as at Rove Camp de Laure (Bouches-du-Rhône) (Courtin 1975). Individual burials are becoming more common and small cemeteries make their appearance (Lemercier \& Tchérémissinoff 2011) as at Mondragon - Les Juilléras (Vaucluse) (Lemercier 2002). The sites are concentrated at the exit of the Rhône valley but are also known well beyond the area of study in small occupation groups.

\section{The protohistoric model}

The sequence presented here can be defined as 'exploration, implantation and diffusion, colonisation and acculturation' and resembles the model proposed by A. Nickels for the Greek colonisation of the Languedoc (Nickels 1983). A first phase, the 'exploration phase', refers to the first contacts between Greeks and indigenous communities. It is characterised by the presence in certain indigenous graves of rare imported drinking vessels. These are interpreted as gifts received in episodic contacts linked to the exploration of the coast by Greek seafarers.

The second phase is connected to the implantation of trading posts in nearby areas. It corresponds to regular contacts and to a first intensification of exchanges as well as to the first attempts at settlement. Objects of Greek tradition increase in number and local workshops are created; their products (grey monochrome ceramics) will soon account for 80 per cent of the fine wares found in the region. Given the absence of a real Greek colony in the Languedoc, Nickels proposes "a permanent settlement of a small group of Phocaeans within —or next to-an indigenous community [...] a hypothesis that best fits the observed archaeological data" (1983: 418). This phase is also marked by attempts to reach the interior of the land.

The third phase sees the establishment of an offshoot of Massalia (Agde). Its cemeteries show the presence of diverse rites enacted by different parts of the population "which implies [...] the cohabitation within the trading post itself of elements of diverse origins" (Nickels 1983: 423). This period is also characterised by a significant intensification in exchange, in which objects of diverse origins are found together with local and Greek products.

(C) Antiquity Publications Ltd. 


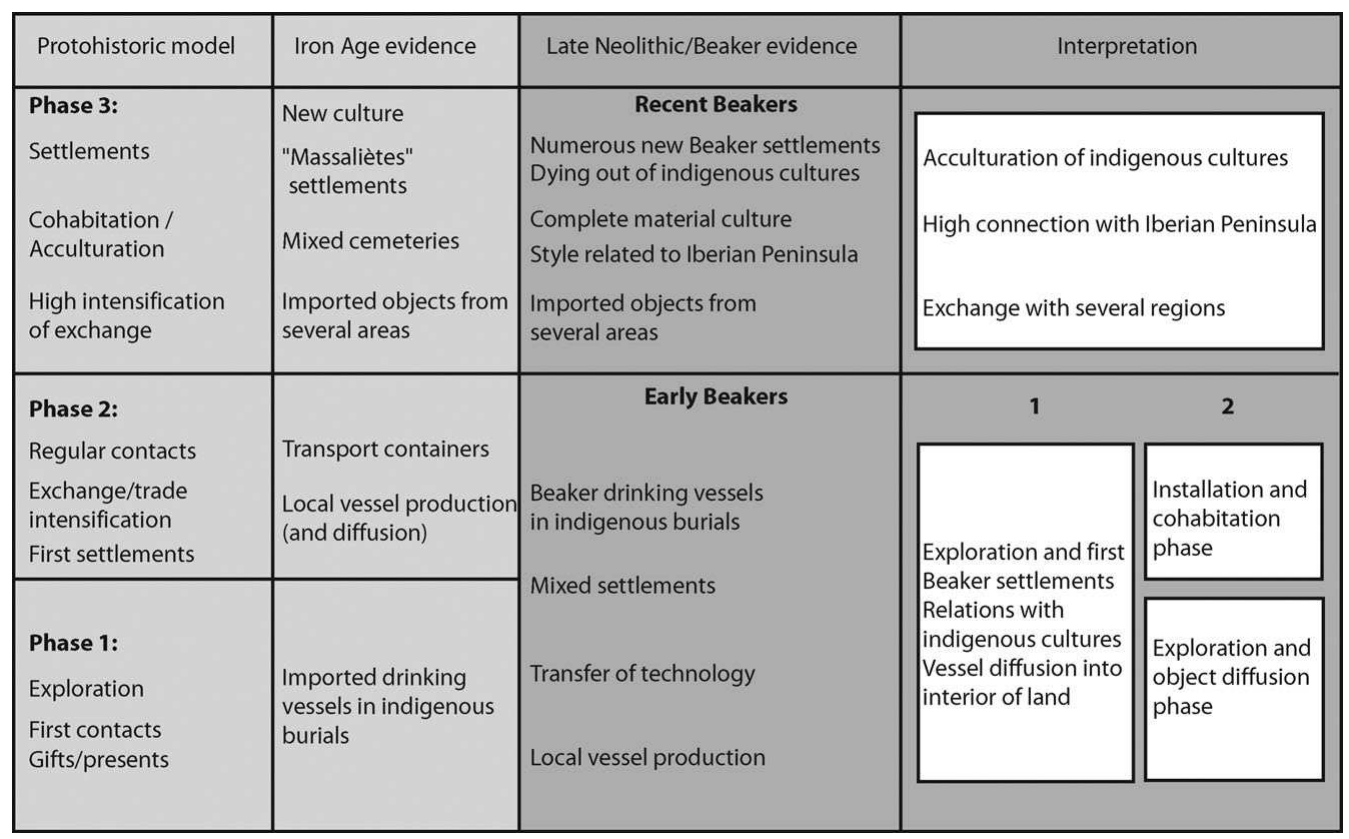

Figure 4. Protohistoric model and Beaker data: interpretation.

\section{Interpretation, extension and limitations of the model}

Using this Iron Age model as an analogy, it is possible to attempt a similar historic reading of the data relating to the Beaker phenomenon in Mediterranean France (Figure 4). It consists of three stages, overlapping those of the protohistoric model, which we can define as exploration, acculturation and independent development (Lemercier 1998a \& b).

\section{First stage: exploration and first contact}

This first stage corresponds to the arrival by sea into the area under study of the first Beaker elements. Comparisons lead us quite systematically to the Iberian Peninsula and Portugal in particular (Salanova 2000; Lemercier 2004a \& b), regions that remain serious candidates for the area of origin of the European Beaker phenomenon as shown by the distribution of radiocarbon dates (Müller \& van Willigen 2001) and by local sequences (Kunst 2001). It is still impossible to identify a putative first phase of contact marked by exchanges and gifts, but the observed configuration, with its principal sites along main routes, and artefacts distributed towards the interior among the local population (often in burials), fits the description of the first phases of Greek colonisation in the Languedoc very well. In parallel, we see that the first establishments, in Provence, are on specific, naturally defended hill-top sites, but within local communities whose material culture is well represented on these sites. The absence of such sites in eastern Languedoc, in the zone of the Fontbouisse group, but the presence of isolated Beaker artefacts, are connected to a different historic situation and to different relationships between local communities and Beaker-using people. The Beaker

(C) Antiquity Publications Ltd. 
phenomenon only takes hold in the region somewhat later, at the time when the regional Rhodano-Provençal group develops (Lemercier 2004a; Lemercier \& Furestier 2009).

\section{Second stage: implantation and exchange networks}

The second significant stage is characterised by the development of regional Beaker groups-Pyrenean and Rhodano-Provençal—and probably corresponds to the third phase of the protohistoric model. While the local Late Neolithic cultures were well attested in the first stage, they seem to disappear in the second. The settlements of the Rhodano-Provençal group are often established on the disused remains of settlements of the Fontbouisse group, as at Langlade - Le Vignaud 3 (Gard) where two Beaker vessels were found; they were already old and already present in the Fontbouisse period (Hayden et al. 2011).

It is at this time that the whole of the region sees the arrival of Beaker establishments, now no longer restricted to the coast or the main valleys. There are many lowland sites and the assemblages show the development of a fully fledged material culture. The two regional groups still show an Iberian affinity, with the decorated pottery of the Rhodano-Provençal group clearly exhibiting resemblances with the Spanish Ciempozuelos group. However, certain vessel forms, some tools (the microlith crescents) and some objects of personal ornament (the arc-shaped pendants) evoke other more northerly or easterly provenances or influences. This stage therefore corresponds to a double phenomenon. On the one hand it seems that the acculturation of the indigenous communities was fairly swift, as shown by the replacement by a new material culture of Beaker type, different from the earlier Beaker manifestations but also respecting some local traditions. On the other hand, while relationships with the Iberian Peninsula remain very strong - to the point of raising the possibility that some population movement actually took place-the presence of certain objects suggests that numerous contacts or exchanges with other regions of Beaker Europe are likely to have taken place. Furthermore, the Beaker coarse wares identified in this phase in Mediterranean France show strong affinities with other regional groups in France, Switzerland (Besse 2003) and even central Italy (Leonini 2003), perhaps giving more insight into communities sharing a common identity than the differences exhibited by the regional decorative styles of the fine wares can reveal.

\section{Third stage: the end of Beaker traditions}

The appearance of barbed-wire pottery is distinctly outside the proposed model and corresponds to a new cycle where the former privileged relationship with the Iberian Peninsula disappears. Although some elements, such as the lithic industry, remain anchored in local traditions, the pottery shows a strong influence from the Italic area, both in vessel shapes and in the style of decoration. If the origin of the barbed-wire decoration style is perhaps to be sought in the north-western Balkans (Lemercier 2004b), the vessel forms are more reminiscent of central and north-Italian Beakers. The assemblages known from southern France at this time belong to a material culture that has a strong Beaker ascendency, both local and Italic. The development of new fortified sites no doubt betrays a new situation. The appearance in Mediterranean France of small bronze objects does not, however, seem

(C) Antiquity Publications Ltd. 
to indicate a significant change in the material culture or in the lifeways of communities that are still very much anchored in Neolithic traditions. It is only in the eighteenth century $\mathrm{BC}$ that the Bronze Age really starts in our region.

\section{Extension, limitations and lessons from the model proposed}

If the cited protohistoric model seems a satisfactory way of interpreting the Beaker evidence in Mediterranean France, it may be possible to extend it to other areas. An assessment of the data available in central Italy and Sardinia has led to a similar proposal (Lemercier $e t$ al. 2007) for the spread of the Beaker phenomenon along the north-western and Tyrrhenian coast of the Mediterranean. On the continent, a similar evolution can be envisaged for central Spain (Harrison \& Mederos Martin 2001). The Beaker assemblages known on the Atlantic coast of France could also be interpreted in the same way; this would then be a remarkable phenomenon, starting on the Atlantic coast of the Iberian Peninsula and reaching out towards the north Atlantic, the interior of the Peninsula and the Mediterranean area, whose origins are probably to be sought in the cultures that developed in Portugal and in southern Spain during the third millennium BC.

This first diffusion appears to have a strong impact on indigenous cultures, to the point of sometimes transforming them radically, while others seem to have resisted for a while (the Fontbouisse group in the Languedoc) or for a very long time (the Terrina group in Corsica). At the same time it opens up routes of communication and exchange across Europe, which will see people, objects and ideas circulate in many ways and directions during the middle Beaker phase, creating privileged relationships between the new cultural groups that emerged from this first diffusion.

It is however unlikely that this model is applicable to the whole of Mediterranean Europe in Beaker times. Conditions of dispersal, of implantation and of evolution of the Beaker phenomenon may have led to quite different paths being followed in the interior of the continent or in more northerly regions. The length of the Beaker cycle, and, more to the point, its remarkable spread speak against the application of a single model.

In terms of limitations, trying to answer why the diffusion happened in the first place remains a question without a satisfactory answer. The protohistoric model, which fits specific economic and political conditions, cannot be transferred directly in this domain. The correlation between concentrations of Beaker material and copper deposits (Lewthwaite 1987) does not seem to be secure in all regions. It is highly likely that the reasons for the Beaker phenomenon are to be sought as much in its areas of origin as in those where it spread and that these reasons are as multiple and as complex as those at the heart of the spread of the Neolithic mode of life for example.

When it comes to the question of the nature of the Beaker phenomenon itself, we can however respond to L. Salanova who described it as "neither people nor package" (Salanova 2000: 17): the Beaker phenomenon represents both people and 'package'. People because the first diffusion happens through groups of people, attested by the transfer of techniques, and 'package' because Beaker artefacts are well and truly reaching indigenous communities affected by the phenomenon. Beyond that, we must not discount ideology as a factor (Strahm 1995), since these objects have a sometimes significant funerary dimension.

(C) Antiquity Publications Ltd. 
To conclude, we contend that the idea of a model borrowed from a later prehistoric period for a set of circumstances that occurred more than 2000 years earlier is no less valid than analogies derived from ethnoarchaeology which consider situations that happened after an interval of some 4500 years in areas thousands of kilometres away, in cultural and environmental contexts that are far more alien.

\section{References}

AMBERT, P. 2003. Contribution à l'étude du Campaniforme en Languedoc central méridional. Bulletin de la Société Préhistorique Française 100(4): 715-32.

Barge-Mahieu, H. 1992. Le Campaniforme dans le Midi de la France, origine et identité culturelle. Marseille: Etudes et Prospectives Archéologiques.

BEsse, M. 2003. L'Europe du 3e millénaire avant notre ère: les céramiques communes au Campaniforme (Cahiers d'Archéologie Romande 94). Lausanne: Aventicum.

BILL, J. 1973. Die Glockenbecherkultur und die frühe Bronzezeit im französischen Rhonebecken und ihre Beziehungen zur Südwestschweiz. Basel: Schweizerische Gesellschaft für Ur-und Frühgeschichte.

BLAISE, E. 2010. Economie animale et gestion des troupeaux au Néolithique final en Provence : approche archéozoologique et contribution des analyses isotopiques de l'émail dentaire, (British Archaeological Report International Series 2080).Oxford: John \& Erica Hedges.

Bocquenet, J.P., O. Lemercier \& A. MÜller. 1998. L'occupation campaniforme du site perché du Col Sainte-Anne (Simiane-Collongue Bouches-du-Rhône - France). Séries céramiques, structures d'habitat et espaces domestiques, in Proceedings of the XIII International Congress of Prehistoric and Protohistoric Sciences, Forli (Italia) 8-14 September 1996, Section 10: The Copper Age in the Near East and Europe: 159-66. Forli: Abaco.

Buisson-Catil, J. \& J. Vital (ed.) 2002. Ages du Bronze en Vaucluse (Notices d'Archéologie Vauclusienne 5, Travaux du Centre d'Archéologie Préhistorique de Valence 4). Avignon: A. Barthélémy.

Convertini, F. 1996. Production et signification de la céramique campaniforme à la fin du 3ème millénaire av. J.C. dans le sud et le centre-ouest de la France et en Suisse occidentale (British Archaeological Reports International Series 656). Oxford: Tempus Reparatum.

- 2009. Céramiques campaniformes et sépultures collectives de l'Aude: origine et statut du standard, in De Méditerranée et d'ailleurs, mélanges offerts à Jean Guilaine: 221-34. Toulouse: Archives d'Ecologie Préhistorique.
Courtin, J. 1967. La culture du vase campaniforme en Provence, note préliminaire. Cahiers Ligures de Préhistoire et d'Archéologie 16: 27-36.

- 1974. Le Néolithique de la Provence (Mémoire de la Société Préhistorique Française 11). Paris: Klincksieck.

- 1975. Un habitat fortifié du Bronze ancien en Basse-Provence: le Camp de Laure. Bulletin $d u$ Museum d'Histoire Naturelle de Marseille 35: 218-40.

- 1976. Les civilisations de l'Age du Bronze en Provence, le Bronze ancien et le Bronze moyen en Provence, in J. Guilaine (ed.) La Préhistoire française II: les civilisations néolithiques et protohistoriques de la France: 445-51. Paris: CNRS.

- 1978. Quelques étapes du peuplement de la région de l'Etang de Berre au Post-glaciaire. Bulletin Archéologique de Provence 1: 1-36.

Courtin, J., A. D’ANNA \& AHCL. 1985. La céramique campaniforme du site des Lauzières, Lourmarin, Vaucluse. Bulletin Archéologique de Provence 15: 5-9.

FURESTIER, R. 2007. Les industries lithiques campaniformes du sud-est de la France (British Archaeological Reports International Series 1684). Oxford: John \& Erica Hedges.

Furestier, R., J. Cauliez, N. Lazard, O. Lemercier, M. Pellissier \& J. Courtin. 2007. 1974-2004: le site du Fortin-du-Saut (Châteauneuf-lès-Martigues, Bouches-du-Rhône) et le Campaniforme 30 ans après, in J. Evin (ed.) Un siècle de construction du discours scientifique en Préhistoire. Actes du XXVIe Congrès Préhistorique de France, Avignon, 21-25 septembre 2004, Volume 2: 297-310. Paris: Société Préhistorique Française.

Gallay, A. 2001. L'énigme campaniforme, in F. Nicolis (ed.) Bell Beakers today: pottery, people, culture, symbols in prehistoric Europe: 41-57. Trento: Servizio Beni Culturali.

GuILAINE, J. 1967. La civilisation du vase campaniforme dans les Pyrénées françaises. Carcassonne: Gabelle.

- 1976. La civilisation des gobelets campaniformes dans la France méridionale, in J. Guilaine (ed.) $L a$ Civilisation des vases campaniformes, IXe Congrès de l'UISPP, Colloque XXIV: 197-213. Nice: UISPP. 
Guilaine, J., J. Vaquer, J. Coularou \& F. Treinen-Claustre (ed.). 1989. Médor / Ornaisons. Archéologie et écologie d'un site de l'Age du Cuivre, de l'Age du Bronze final et de l'Antiquité tardive. Toulouse: CASR; Carcassonne: Archéologie en Terre d'Aude.

Guilaine, J., F. Claustre, O. Lemercier \& P. SABATIER. 2001. Campaniformes et environnement culturel en France méditerranéenne, in F. Nicolis (ed.) Bell Beakers today: pottery, people, culture, symbols in prehistoric Europe: 229-75. Trento: Servizio Beni Culturali.

Harrison, R.J. \& A. Mederos Martin. 2001. Bell Beakers and social complexity in central Spain, in F. Nicolis (ed.) Bell Beakers today: pottery, people, culture, symbols in prehistoric Europe: 111-24. Trento: Servizio Beni Culturali.

Hayden, C., E. Blaise, R. Furestier, O. Lemercier, J. Linton, M. Perez, W. Smith \& D. Todisco. 2011. Le Vignaud 3, Chemin du Puits Neuf (Langlade, Gard): du Fontbouisse au Campaniforme, in I. Senepart, T. Perrin, E. Thirault \& S. Bonnardin (ed.) Marges, frontières et transgressions, actualité de la recherche (8e Rencontres Méridionales de Préhistoire Récente, Marseille, 7-8 novembre 2008): 439-48. Toulouse: Archives d'Ecologie Préhistorique.

Jallot, L., M. Bordreuil, J. Vital \& R. Vejus. 1996. Un nouveau site à "décor barbelé" dans le Gard (Aven Roger, Saint-Jean-de-Maruéjols-et-Avéjan). Etat de la question dans le midi de la France, in C. Mordant \& O. Gaiffe (ed.) Cultures et sociétés du Bronze ancien en Europe, Actes du 117 e Congrès National des Sociétés Savantes, Clermont-Ferrand 1992: 339-48. Paris: CTHS.

KunST, M. 2001. Invasion? Fashion? Social rank? Consideration concerning the Bell Beaker phenomenon in Copper Age fortifications of the Iberian Peninsula, in F. Nicolis (ed.) Bell Beakers today: pottery, people, culture, symbols in prehistoric Europe: 81-90. Trento: Servizio Beni Culturali.

LEMERCIER, O. 1998a. Phénomène, culture et tradition: statuts et rôles du Campaniforme au IIIe millénaire dans le sud-est de la France. Bulletin de la Société Préhistorique Française 95(3): 365-82.

- 1998b. The Bell Beaker phenomenon in the southeast of France: the state of research and preliminary remarks about the TGV-excavations and some other sites of Provence, in M. Benz \& S. van Willigen (ed.) Some new approaches to the Bell Beaker phenomenon. Lost Paradise. . .? (Proceedings of the 2nd Meeting of the "Association Archéologie et Gobelets", Feldberg (Germany), 18th-20th April 1997) (British Archaeological Report, International Series 690): 23-41 Oxford: Archaeopress.
- 2002. Les occupations néolithiques de Mondragon Les Juilléras (Vaucluse), in Archéologie du TGV Méditerranée, Fiches de Synthèse. Tome 1: la Préhistoire (Monographies d'Archéologie Méditerranéenne 8): 147-72. Lattes: UMR 154 du CNRS/ADAL.

- 2004a. Explorations, implantations et diffusions: le "phénomène" campaniforme en France méditerranéenne. Bulletin de la Société Préhistorique Française 101(2): 227-38.

- 2004b. Les Campaniformes dans le sud-est de la France (Monographies d'Archéologie Méditerranéenne 18). Lattes: UMR $154 \mathrm{du}$ CNRS/ADAL.

- 2004c. Historical model of settling and spread of Bell Beaker culture in Mediterranean France, in J. Czebrezuk (ed.) Similar but different: Bell Beakers in Europe (Poznan Symposium, Poland, 26-29 May 2002): 193-203. Poznan: Adam Mickiewicz University.

- 2007. La fin du Néolithique dans le sud-est de la France: concepts techniques, culturels et chronologiques de 1954 à 2004, in J. Evin (ed.) Un siècle de construction du discours scientifique en Préhistoire, Actes du XXVIe Congrès Préhistorique de France, Avignon, 21-25 septembre 2004, Volume 1: 485-500. Paris: Société Préhistorique Française.

- In press. The Mediterranean French Beaker transition, in H. Fokkens \& F. Nicolis (ed.) Beakers in transition (EAA congress, The Hague, 2010). Leiden: Sidestone.

Lemercier, O. \& R. Furestier. 2009. Après les "vrais campaniformes": le Rhodano-Provençal dans le sud-est de la France, in De Méditerranée et d'ailleurs, mélanges offerts à Jean Guilaine: 391-402. Toulouse: Archives d'Ecologie Préhistorique.

Lemercier, O. \& C. GilaberT. 2009. Approche chronoculturelle de l'habitat de la fin du Néolithique en Provence, in A. Beeching \& I. Sénépart (ed.) De la maison au village: l'habitat Néolithique du sud de la France et du nord-ouest méditerranéen. Actes de la table ronde de Marseille, 23-24 mai 2003 (Mémoire de la Société Préhistorique Française 48): 255-66. Paris: Société Préhistorique Française.

LEMERCIER, O. \& Y. TCHÉRÉMISSINOFF. 2011. Du Néolithique final au Bronze ancien: les sépultures individuelles campaniformes dans le sud de la France, in L. Salanova \& Y. Tchérémissinoff (ed.) Les sépultures individuelles campaniformes en France (Supplément à Gallia Préhistoire 41): 177-94. Paris: CNRS.

(C) Antiquity Publications Ltd. 


\section{Interpreting the Beaker phenomenon in Mediterranean France}

Lemercier, O., V. LeOnini, P. Tramoni, \& R. FurEstiER. 2007. Campaniformes insulaires et continentaux de France et d'Italie méditerranéennes: regards croisés (relations et échanges entre Corse, Sardaigne, Toscane et Midi français dans la seconde moitié du troisième millénaire avant notre ère), in A. D'anna, J. Cesari, L. Ogel, \& J. Vaquer (ed.) Corse et Sardaigne préhistoriques. Relations et échanges dans le contexte méditerranéen, Actes du 128e Congrès du CTHS, Bastia 2003 (Documents Préhistoriques 22): 241-51. Paris: CTHS, Association des Chercheurs en Sciences humaines - Domaine corse.

Lemercier, O., R. Furestier, \& E. Blaise (ed.) 2010. 4e millénaire: la transition du Néolithique moyen au Néolithique final dans le sud-est de la France et les régions voisines (Monographie d'Archéologie Méditerranéenne 27). Lattes: UMR 5140 du CNRS/ADAL.

Lemercier, O., R. Furestier, A. Müller, E. Blaise, C. Bouville, F. Convertini, \& L. Salanova. 2011. La sépulture individuelle campaniforme de La Fare, Forcalquier (Alpes-de-Haute-Provence), in L. Salanova \& Y. Tchérémissinoff (ed.) Les sépultures individuelles campaniformes en France (Supplément à Gallia Préhistoire 41): 145-59. Paris: CNRS.

LEONINI, V. 2003. La ceramica comune del Campaniforme dell' Italia centro-settentrionale nella prospettiva di una provincia culturale europea. Unpublished doctoral dissertation, Universita' degli Studi di Pisa.

LEWTHWAite J. G. 1987. The Braudelian Beaker: a Chalcolithic conjecture in Western Mediterranean prehistory, in W.H. Waldren \& R. C. Kennard (ed.) Bell Beakers of the Western Mediterranean: definition, interpretation, theory and new site data (Oxford International Conference 1986) (British Archaeological Report International Series 331): 31-60. Oxford: British Archaeological Reports.

Müller, J. \& S. van Willigen. 2001. New radiocarbon evidence for European Bell Beakers and the consequences for the diffusion of the Bell Beaker phenomenon, in F. Nicolis (ed.) Bell Beakers today: pottery, people, culture, symbols in prehistoric Europe: 59-80. Trento: Servizio Beni Culturali.

NiCKELS, A. 1983. Les Grecs en Gaule: l'exemple du Languedoc, in Modes de contacts et processus de transformation dans les sociétés anciennes. Actes du Colloque de Cortone, mai 1981 (Collection de l'Ecole Française de Rome 67): 409-28. Pise-Rome: Ecole Française de Rome.
RouDIL, J.-L. 1993. Les premiers métallurgistes de l'Ardèche, l'âge du Cuivre et l'âge du Bronze. Privas: Conseil départemental de la Culture de l'Ardèche.

SALANOVA, L. 2000. La question du Campaniforme en France et dans les îles anglo-normandes: productions, chronologie et rôles d'un standard céramique (Documents Préhistoriques 13). Paris: CTHS, Société Préhistorique Française.

SAUZADE, G. 1983. Les sépultures du Vaucluse du Néolithique à l'Age du Bronze (Etudes Quaternaires 6). Paris: Editions LPHP/IPH.

Sauzade, G., J. Courtin \& G. Chabaud. 1974. Le dolmen 1 de San-Sébastien, communes de Plan de la Tour, Sainte-Maxime (Var), in Congrès Préhistorique de France, 20e session, Martigues 1974: 581-93. Paris: Société Préhistorique Française.

STrahm, C. 1995. Das Glockenbecher-Phänomen: ein Seminar (Freiburger Archaeologische Studien, 2). Freiburg in Breisgau: Institut für Ur-und Frügeschichte der Universität.

VAN DER Linden, M. 2006. For Whom the Bell Tolls: social hierarchy vs social integration in the Bell Beaker culture of southern France (third millennium BC). Cambridge Archaeological Journal 16: 317-32.

VAquer, J. 1998. Le Mourral, Trèbes (Aude): a fortified languedocian late Neolithic site reoccupied by Bell Beakers, in M. Benz \& S. van Willigen (ed.) Some new approaches to the Bell Beaker phenomenon. Lost Paradise...? (Proceedings of the 2nd Meeting of the "Association Archéologie et Gobelets", Feldberg (Germany), 18th-20th April 1997) (British Archaeological Report International Series 690): 15-21. Oxford: Archaeopress.

Vignaud, A. 2002. Aix-en-Provence - Clos Marie-Louise, in Archéologie du TGV Méditerranée: fiches de synthèse. Tome 2: la Protohistoire (Monographies d'Archéologie Méditerranéenne 9): 573-76. Lattes: UMR 154/ADAL.

VITAL, J. 2000. Composantes culturelles des premières productions céramiques du Bronze ancien dans le sud-est de la France, in Bilan Scientifique de la Région PACA 1999: 205-7. Aix-en-Provence: DRAC, Ministère de la Culture.

Received: 24 January 2011; Accepted: 30 March 2011; Revised: 25 May 2011

(C) Antiquity Publications Ltd. 